\title{
Deixis in Arabic and English: A Contrastive Approach
}

\author{
Fatima Ahmad Al Aubali \\ Faculty of Letters, University of Sana'a, Yemen \\ E-mail: fadfaun@yahoo.fr
}

Received: 06-12- 2014

Published: 01-07- 2015

\author{
Accepted: 07-02- 2015
}

doi:10.7575/aiac.ijalel.v.4n.4p.118
Advance Access Published: February 2015

URL: http://dx.doi.org/10.7575/aiac.ijalel.v.4n.4p.118

\begin{abstract}
In this article, the author will investigate the way of utilizing deictic expressions for social relations as well as diplomacy, which are of great importance to translators, teachers and diplomats. Recognizing the five types of deixis and their implicaions and different connotations, the author will show the similarities and differences between the two languages and how they are used. The consequences of misunderstanding these differences might lead to diplomatic conflict and complete failure of translating the speaker's intention from the source language to the target language which may lead to world conflict. Thus the author will point out the semantic features and pragmatic functions of personal, spatial and temporal deixis of English, and Arabic pointing out similarities and differences. Thus the writer points out their importance to language teaching which is of great importance. However, the translation is not only for academic purposes but for the international community at large.
\end{abstract}

Keywords: deixis, social- discourse, anaphora, Indexicals, politeness, connotations, pragmatics

\section{Introduction}

The word 'deixis' derived from Greek 'deiktiktikos' is used in modern Western linguistics to refer to certain personal, spatial and temporal elements which events on the basis of spatio-temporal dimensions. There are three main types of deixis: person, place and time, and two minor ones in English and other languages including Arabic, discourse deixis and social deixis. The present paper discusses mainly the first three types; it only touches lightly on the other two minor types; it points out the basic similarities and differences in deixis between the two languages.

In philosophy deictic elements are usually called indexical expressions or just indexicals, a term also used by Peirce (1931:58) in the sense of deixis.

As expected, the Arab linguists and grammarians have not discussed the notion of deixis in one comprehensive topic; it occurs in scattered places like pronouns, demonstratives, verbs, adverbs and particles. In discussing these grammatical elements, the Arab grammarian makes casual reference to the notion of deixis.

\subsection{Deixis and Anaphora}

Both deixis and anaphora share the deictic or pointing feature, but in deixis the pointing feature points to the context of utterance or context of situation; whereas in anaphora it points to the antecedent or to its referent. The example below illustrates the difference:

The pronouns 'I ' and ' you' refer to the speaker and the addressee, who can be recognized from the context of situation; they are deictic elements.

\subsubsection{Want to speak to Peter Black. Do you know where he is?}

The pronouns 'I, you' refer to the speaker and the addressee, who can be recognized from the context of situation; they are deictic elements. The pronoun 'he' refers to the referent of the expression 'Peter Black'; it is therefore anaphoric. Following Bühler (1934, p. 120 ), some linguists distinguish between an anaphoric function of a pronoun as that of 'he' in (1), where it points to the referent of a preceding antecedent, and the cataphoric function of a pronoun, where it points to the referent of a forward antecedent as in (2):

\subsubsection{Because he was angry, Peter resigned.}

Assuming that 'he' refers to the referent of 'Peter', we say that 'he 'is used cataphorically

Traditionally, anaphora covers both the more usual backward and the less usual forward anaphora. This is the use adopted in this research.

There is another point which needs to be clarified before this section is concluded, namely: What does an anaphoric pronoun refer to? So far it has been stated that it refers to the referent of the antecedent i.e. it is co-referent with its antecedent. Thus in (1) above 'he' refers to the referent of the expression 'Peter Black'. There is, however, an older and traditional view which says that a pronoun refers to the antecedent expression rather than the referent. In this use adopted by Bloomfield and others a pronoun is a substitute of a noun or a nominal expression (a noun phrase); often no distinction was drawn between the two units, which sometimes results in considerable confusion. In the present article 
the more recent view is adopted, where an anaphoric pronoun refers to the referent of the antecedent. This is also the use found in various philosophical schools

How do traditional Arab grammarians envisage the antecedent and the referent of a pronoun? The following standard definition of the pronoun in Arabic may shed some light at this point. الضمير اسم جامد يدل على متكلم او مخاطب او غائب) (The pronoun is an indeclinable noun which points to a speaker, an addressee or an absent person (Hassan, 1975, p. 217). It is clear from this definition that the first and the second pronouns are viewed as deictic, and the third person pronoun either anaphoric or deictic pointing to the referent of an expression. This will be confirmed later when the author discusses the antecedent of the pronoun (Hassan, 1975, p., 255).

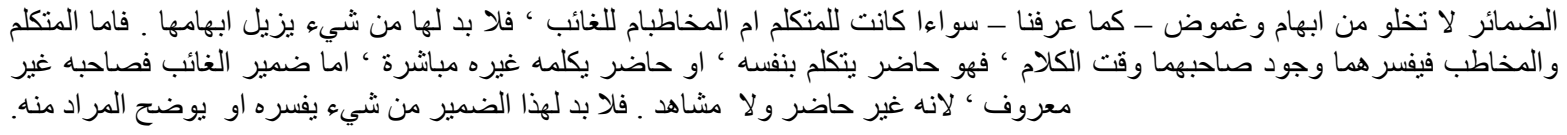

(Pronouns are characterized by being vague or ambiguous - as we have seen - whether they belong to the first person or second person or third person. There must be something to disambiguate them or eliminate their vagueness. As for the first person and the second person, they can be identified by the fact that their referents are present at the time of utterance; one is present and speaking and the other is present and addressed by the speaker directly. As for the third person pronoun, its referent is unknown because he is neither present nor witness. Therefore the third person should have something to identify its referent.

It should be noted that the interpretation of the third person is different from that of modern linguistics, where the referent is neither the speaker nor the addressee; he may be present or witness but he is not a participant in the speech event. The Arabic definition is influenced by the designation of the third person pronoun as ضمير الغائب (literally the pronoun of the absent).

\section{Person Deixis}

Pronoun deixis grammaticalizes the participants' roles of the speaker, the addressee and the one who is neither the speaker nor the addressee. These three roles of the speaker are known as the first person, the second person and the third person. The word 'person' in Western tradition is derived from a 'persona' an actor wearing a mask on the stage. Technically, the third person is not a participant since he/she plays no active role in the speech activity.

Morphologically, English pronouns are realized as separate morphemes while Arabic pronouns are realized, in their unmarked form, as affixes attached to verbs, nouns and particles. They are also realized markedly as separate forms indicating emphasis or contrast.

In English there are two first person pronouns, 'I' and 'we' showing number but not gender. This is also true of the first and second persons in Arabic: نحن The plural of the first person in both languages is slightly different from the usual sense of plural; in that 'we' does not mean ' $1+1+1$ ' as the plural 'books means 'book + book + book'; the plural 'we' and نحن rather means $1^{\text {st }}+2$ nd $+3^{\text {rd }}$ persons' or ' $1^{\text {st }}+3^{\text {rd }}$ persons'; the first is called inclusive plural and the second exclusive, as in the examples below.

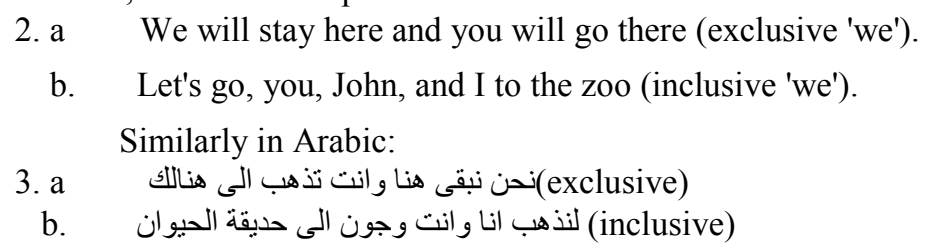

Note the order of the three pronouns is different in English, ' $2^{\text {nd }}+3^{\text {rd }}+1^{\text {st }}$ from Arabic, $1^{\text {st }}+2^{\text {nd }}+3^{\text {rd }}$.

A greater difference is found in the pronouns of the second person in English and Arabic. English has only one form, 'you' which realizes the role of the second person participant or the addressee. Arabic second person pronouns are no fewer than five showing number, gender and case انت (you-sing-masc.), انت (you-sing-fem), انتن انتما (pl- masc.), and (pl-fem). To this may be added the forms representing case: o case covering the accusative and the genitive. In practice this means that Arabic refers to the second person pronoun in a more specific way, identifying the referent in terms of number, gender and case, besides the participant role. The Yiddish joke in Levinson (1983, p. 68) based on the identity of 'you' for masculine and feminine cannot be rendered into Arabic, which uses two different forms for the two genders:

\begin{abstract}
A melamed [Hebrew teacher] discovering he had left his comfortable slippers back in the house, sent a student after them with a note for his wife. The note reads "Send me your slippers with this boy'. When the boy asked why he had written 'your slippers', the melamed answered: 'Yold!' if I wrote 'my' slippers, she would read 'my' slippers and would send her slippers. What could I do with her slippers? So I wrote 'your' slippers, she will read 'your' slippers and send me mine' (Rosten, 1968, pp., 443-4; cited by Levinson, 1983, p., 68).
\end{abstract}

Probably in most languages including English and Arabic, the basic function of the third person pronoun is anaphoric rather than deictic. They often point to the referent of their antecedent (a referent of) the expression in the co-text) 
rather than to a referent in the context of situation... However, a third person pronoun may have a deictic function; in this case the utterance of the pronoun is normally accompanied by a gesture.

4. a He is reading a short story. (The speaker pointing to a man).

Under the same conditions the third person pronoun in ${ }^{-}$would be deictic.

4. b انه يقرأ قصة قصبيرة

Out of context may be in several ways ambiguous. The third person pronoun in (5) reads with a normal stress can have two interpretations.

5. The manager smiled when he left the room.

The pronoun 'he' may be anaphoric co-referential with 'the manager' or anaphoric but co-function is meant (Lyons, 1977, p. 660). The subordinate clause may be placed initially.

6. When he left the room, the manager smiled.

The pronoun has the same two readings as in (5). The interpretation of the third person pronoun is more restricted in coordination; its referential function is confined to backward anaphoric use. Thus only (7) has two interpretations, (8) has one interpretation only.

7. The manager smiled and he left.

8. He left and the manager smiled.

In (7) the pronoun 'he' may be co-referential with 'the manager' or with another expression; in (8) the pronoun 'he' cannot be co-referential with 'the manager', it can only point to the referent of another expression.

The points discussed above also apply to the use of the third person pronoun in Arabic, with one exception: forward anaphora illustrated in (6). Forward anaphora is highly restricted in Arabic; example (6) nearly always occurs with the antecedent preceding the pronoun.

غادر الددير و هوير ابتسم .

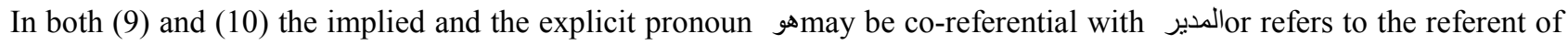
another expression.

With a strong stress, the pronoun in (11) can be deictic, anaphoric co-referential or anaphoric non-referential.

Rendered into Arabic, the strong stressed pronoun would be expressed by a separate morpheme.

12. ابتسم الدير وهو يغادر

The Arabic sentence in (12) will have the same deictic and anaphoric readings of the corresponding English sentence in (11).

The third person pronouns are differently realized in English and Arabic. English has four pronouns; 'he, she, it, they' minimally marked for gender, number, and case. The forms he, she, it are singular and show personal and non-personal gender; the plural form of the three pronouns is 'they', which lacks gender. Likewise Arabic third person pronouns are marked for gender, number and case; but Arabic gender is grammatical rather than personal and identifies the referent as either masculine or feminine; there are three numbers: singular, dual, and plural, all of which show gender.( ' هو " هي ' هي (هما؛ هم ؛ هن (ه) except the dual which is the same for masculine and feminine. The distinctions of gender in English 'he', 'she', and 'it' help considerably to identify the referent, but the realization of the plural in one form, 'they/ works unfortunately in the other direction. Arabic gender with its minimal two-way grammatical basis is compensated for by the fact that each of the two genders is relevant for singular and plural هو "هي "هما؛ هم ؛ هن- (ه).

\section{Place Deixis}

Place deixis identifies the referent on the basis of location; the point of reference being proximity from the speaker at the time of utterance. The English place deictic elements are the demonstratives, 'this -that', the adverbs, 'here-there' and the definite article 'the'; besides certain verbs like 'come-go', which show direction or towards the speaker. The spatial deictic elements are egocentrically arranged as follows:

\begin{tabular}{lc} 
Near the speaker & away from the speaker \\
\hline This (these) & that (those) \\
Here & there \\
Come & go
\end{tabular}

The definite article 'the' is neutral with regard to the principle of proximity.

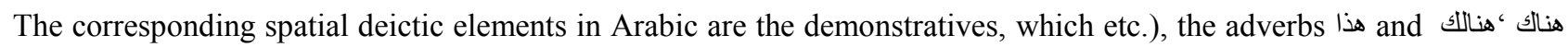
and certain verbs showing direction towards the speaker جاء away from the speaker ذهب. Again these elements may be arranged as follows:

Near the speaker away from the speaker

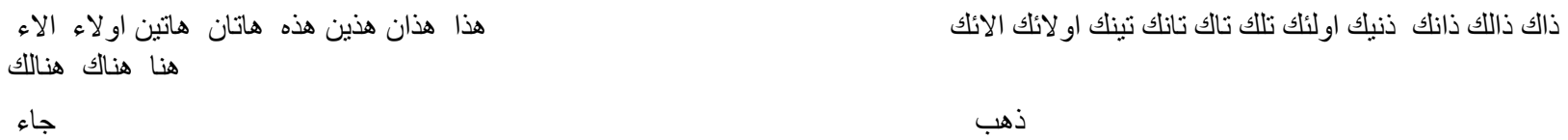


The dimension of proximity in the demonstratives, whether in English or in Arabic is complicated by two other factors, the temporal factor which belongs to the next section, and the psychological factor which tends to use the proximal pronoun for favourable objects and situations and the distal pronoun for unfavourable ones. The precise use of these dimensions in English is too complicated to be formulated into rules (Lyons 1977, p. 668) and the problem is more complicated in Arabic. However, here the two languages seem to show some difference in their use of the demonstratives. English uses the distal' 'that' for unfavourable objects and situations, while Arabic, on the other hand, uses the proximal (هاذا هذه)as the following examples (taken from (Faulkner's Sound and Fury and its Arabic translation by Jabra Ibrahim Jabra) show:

13. Not that blackguard Caddy (Sound and Fury, p. 94) لا هذا النذل ياكادي (Jabra, p. 158)

14. ... Damn that horse damns that horse (Sound and Fury, p. 96) لعنة الله على هذا الحصان لعنة اله على هذا الحصان (Jabra, p. 158).

15. That that grin at you that thing through them (Sound and Fury, p. 95). هذا الي يكثر من خلالهم (Jabra, p. 158).

The definite article in Arabic is realized as a prefix land its use is not based on proximity, but like the English article, on the unique local position and shared between the speaker and the addressee.

Besides the dimension of proximity, the demonstratives also show dimension of nakedness. In English 'this' is marked and 'that' is unmarked (Lyons, 1977, p647), the opposite is true in Arabic, the proximal is unmarked, the distal form (ذاك ) (ذلك) is marked. The following examples illustrate this point.

17. Listen at you, now, Luster said, 'Ain't you something. Thirty-three years old, going on that way. (Sound and Fury, p. 1)

$$
\text { وقال لستر :"اسمعوه ياعالم ـ أليس عجبا أنك في الثالثة و الثلاثين من عمرك ، وتستمر على هذا النحو }
$$

(Jabra, p., 159)

18. الله بسامحك! أنا مجنونة بنت مجانين فدعنا من هذا ، و اسأله عما خالط عقله

(Zuqaq al-Midaq, p. 117)

"God forgive you! All right, so I'm lunatic and so were my parents. Let's forget about that. Just ask him what is on his mind"

19. ابدا لا اشكو هذا مطلقا

(Zuqaq al-Midaq, p. 119)

"Never, never, I am not complaining about that".

There is a positional difference between the English and the Arabic demonstratives. In English a demonstrative, when used as a determiner, precedes the head, in Arabic the 'determiner' and the demonstrative can precede or follow the head.

20. I have read this book.

$$
\text { قرأت هذا الكتاب أو قر أت الكتاب هذا }
$$

The rules governing the pre-and postposition of Arabic demonstratives had not been fully elaborated.

Infomationally, elements preceding the head have an anticipatory function; those following the head have a trailing function (Leech and Short, 1981, p. 225-226); thus the demonstrative determiner in English points forward because it precedes the head; whereas the Arabic demonstrative can look forward or backward,

since it can precede or follow the head.

\section{Time Deixis}

The elements realizing time deixis of English are nouns, 'tomorrow', 'yesterday', 'today'; adverbs 'now' and $\backslash$ then $\backslash$ and

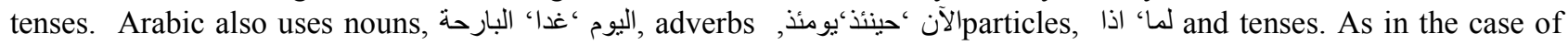

\begin{tabular}{|c|c|}
\hline Near the speaker & Away from the speaker \\
\hline Today tomorrow now present tense & yesterday then past tense \\
\hline الان ان هذان هذين هذه هاتان هاتين اولاء الاء & ذانئن ذالك ذانك ذنيك اولئك تلك تاك تانك تينك او لائك الانكل \\
\hline Present tense & past tense \\
\hline
\end{tabular}
spatial deixis, time deixis may be arranged on the basis of proximity from the speaker as follows:

The demonstrative pronouns in English and Arabic are also used as time deixis, the proximal elements indicating the present; the distal elements pointing to the past, as in the following examples:

22. These are hard times (proximal -temporal).

23. Those were real days (distal-temporal). 
24. هذه اوقات صعبة (proximal -temporal).

كانت تللك ايام العز 25 (distal - temporal).

In English, tense is the most important time deixis; it locates a situation (an event or a state) in the present (including the future) or the past: go-went: Here the point of verb always plays a supplementary role:

26. They arrived here yesterday.

27. She is here now.

Tense in Arabic has a weaker deictic feature; Arabic tenses are usually described as 'relative', which they can take their point of reference either from the speaker-now like English or from any other point in the linguistic context. Thus يكتب may be deictic if it takes its time from the speaker - now as in (28) below in case it is equivalent to the English 'write' or it may derive in time from a point in the co-text as in (29).
28. يكتب الآن
29. رأيته وهو يكتب

The discussion shows that it is important to distinguish between the two (29) يكتب points to the past 'he was writing' because it relates for its time on the previous verb رأى which are types of tenses: absolute tenses which take their point of reference from the speaker-now, and relative tenses which use other points in the context as focus of deixis. The first type, to which English tenses belong, is an important deictic element; the second type, to which Arabic tenses belong, is an important deictic element. Thus the two English tenses, present and past (go-went) are absolute and locate a situation within the time of speaking or before it. It may be said that the past is a marked tense since it places a speech event in the past, whereas the present tense may be considered unmarked because it indicates a present or future action, i.e. a non-past action. Thus the past tense in (26) and the present in (27) above are absolute, and hence deictic. Arabic tenses are realized by the two from imperfect يكتب كتب (29) and perfect be absolute as in (28) or relative as in (29) above; the first type is deictic while the second type is non-deictic.

Since tense in English is deictic, the adverb of time normally plays a supplementary role, as stated above in connection with (26) and (27). In Arabic, on the other hand, adverbs of time play an essential role in determining dimension of the verb form (tense). This point is well- illustrated in the following example:

$$
\text { 30. م نظر هوثرة الى اهل الكوفة و قال: انتم بالامس تقاتلون معاوية لتهدو اسلطانه و اليوم تقاتلون معه لتشدو ا سلطانه }
$$

(Ibn Abdi Rabid Rabhi, 1948, pp. 216-197).

In the direct speech above تقاتلون points to the past since it takes its time from the adverb بالامس (yesterday), the second refers to the present because it derives its time from the adverb اليوم (today). The first verb may be rendered in English as 'were fighting', the second 'are fighting'

Some linguists go as denying that Arabic has any tenses in the European sense of this term; they regard the two forms, imperfect (يكتب) and perfect (كتب) as aspects. This is probably an extreme view which draws no distinction between absolute and relative tenses.

\section{Social Deixis}

Social deixis identifies the participants in an exchange on the two dimensions for rank and familiarity An often quoted example of social distinction is the contrast between 'tu' 'du' in French and 'du and 'Sie' ' in German, the former indicates that the addressee is inferior in rank or close to on the scale of familiarity; the latter, on the other hand, shows that the addressee is superior in rank or distant on the horizontal scale. English has only one second person pronoun 'you' and has no way of drawing a social distinction by means of pronouns. However, the use of titles like 'sir', 'lady', 'your honour', etc. is a mark of social distinction. Arabic has two plural forms, one for males ' females 'However, the use of Arabic has two plural forms, one for males انتن. أنتن . أنت . The male form is sometimes used as an honorific term of address, and usually contrasts with أنت masculine singular 'you'.The honorific use of أنتم is much less common than the French 'vou' and . nearly always confines to addressing male persons

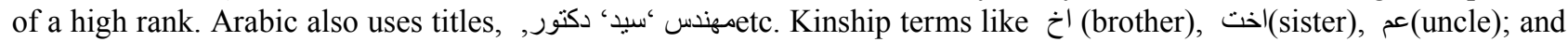

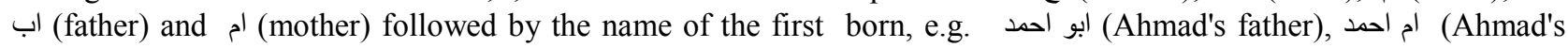
mother) are used to show respect and some familiarity.

\section{Discourse deixis}

Discourse deixis refers to certain expressions which point to a part of discourse in which the deictic element occurs (Levinson, 1983). In both English and Arabic, the proximal demonstratives 'this' and and the distal demonstratives, 'that' and ذالك ‘زللك are used as a discourse deixis, whereas the distal demonstrative always points to a preceding part of discourse. The following examples illustrate these points in English and Arabic:

31. Have you heard this joke? (The joke follows).

32. This is the funniest joke I have heard (referring to the preceding joke).

33. This is the funniest joke I have heard (as in 32).

31a فهل سمعت هذه النكتة ؟

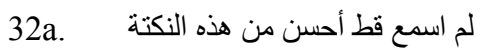


33a. لم اسمع قط احسن من تلك النكتة

While the distal 'that' is more common than the proximal 'this' for backward (anaphoric) reference in English (Ex 33), the opposite is true in Arabic; the proximal هذا هذه is more common than the distal للك تلك anaphoric function.

Arabic also uses the demonstratives in such examples as (34), where English uses (stressed pronouns).

34. دخل احمد وسلمى: هذه تبتسم وذاك يصرخ)(Lit: Ahmad and Selma entered: this (Selma) was smiling and that (Ahmad) was shouting.

35. Ahmad and Selma came in; she was smiling and he was shouting.

The proximal demonstrative in Arabic refers to the nearest part of the discourse, the distal to the farthest. This is also true of example (35), where the same gender (masculine) is involved.

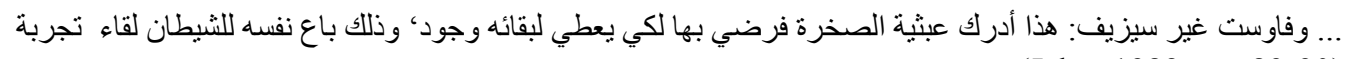

(Jabra 1982, pp. 89-90)

Since the Arabic demonstrative shows gender and number its use in such examples is close to that of the pronouns in the English example in (34) with one essential difference: the demonstrative in Arabic is linked proximally with a part of discourse, hence it is considered discourse deixis, the pronoun in English points to the referent of the antecedent, and is therefore anaphoric. Probably, the purest function of discourse dexis is realized by the Turkish 'bu' ( this one) 'o' (that one) which show gender and number, and their function is merely deictic, the former proximal, the latter distal with regard to the part of discourse in which they occur (cf: Lyons 1977, pp. 669-70).

Discourse deixis also involves the use of the distal demonstrative 'that' in (37) from Lyons 1977, p. 668).

37. A. I have never seen him.

B. That is a lie.

Where the reference is to the entire utterance of the previous speaker, or to the proposition expressed by it. Lyons (1977) terms this image 'impure textual deixis'. In Arabic the proximal demonstrative

38. A. A لم اره قط

B. هذا كذب

Other elements involved in discourse deixis are the so called 'pronouns of laziness' illustrated by the well-known example from Karttunen (Lyons, 1977, pp. 673-4):

39. The man who gave his pay check to his wife was wiser than the man who gave it to his mistress.

The pronoun 'it' is not co-referent with 'his paycheck ' but with the expression 'the pay check' which is not mentioned in the sentence. This may be rendered into Arabic by a corresponding pronoun:

اعطى راتبه لزورجته اعقل من الذي اعطاه لعشيقته

Levinson (1983) finds special cases of discourse deixis in English as in the examples (40) and (41) below (the first is from Lyons 1977, p. 667; the second from Levinson, 1983, p. 86):

40. A. That is a rhinoceros.

B. Spell it for me.

41. This sentence is not true.

The pronoun in (40) refers to 'rhinoceros' as mentioned rather than used; 'that in (41) is taken reflexive]. In (41) Arabic would most probably use a feminine singular form of the third person pronoun:

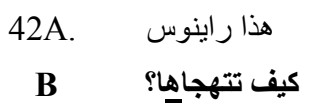

An Arab grammarian would explain the use of the feminine singular Lby saying that the pronoun refers to the implied الكلمة (the word). In (41) Arabic, like English uses the proximal demonstrative هذه as a token reflexive expression.

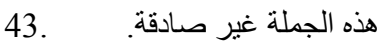

Discourse deixis will probably help to solve the philosophical problem raised such sentences as (41) and (43), which says that these sentences are true if they are false and are false if they are true (Levinson, 1983, p. 80).

\section{Conclusion}

The five types of deixis in English and Arabic show a number of similarities and differences. In person deixis Arabic uses other features besides the deictic dimension, namely, gender, number and case. The contrast is greater between deixis in the two languages in the case of the second person, where English has just one form 'you', whereas Arabic has

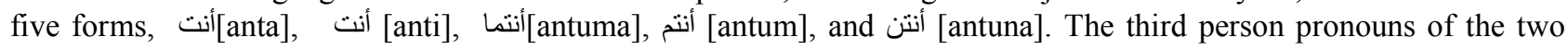
languages also show considerable differences. Arabic has more third person forms, which help to identify the referent. Arabic demonstratives may precede or follow the head and thus have anticipatory (cf . Leech and Short, 1981:225-228, for anticipatory and trailing elements). The proximity dimension of the demonstratives may be neutralized, in which

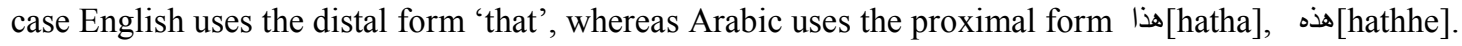


The most important element in time deixis in English is tense, which places a situation before the time of utterance (past) or at the time of utterance or after it (present or future). Tenses in English take their time from the speaker-now: they are sometimes termed 'absolute'. Arabic tenses, on the other hand, may use their point of reference from the speaker now, in which case they are absolute and deictic; or they may use other points of reference; in this case they are relative and non-deictic. This gives adverbs of time a greater role in determining the deictic dimension of the verb than it is the case in English.

The social deixis in Arabic has a plural form of the second person (besides the singular and the dual) but it is less commonly used than the French /vou /tu to indicate a social status. English has only one second person pronoun form. Both languages depend heavily on the sets of titles as means of social deixi.

Discourse deixis involves expressions which point to a part of discourse including the part in which the expression occurs. However, in certain cases Arabic uses demonstratives, whereas English uses pronouns, as in examples (34) and (34a.) The use of the distal and proximal demonstratives as discourse deixis often differs in the two languages; thus English uses the distal 'that' (example 37), where Arabic favours the proximal 1 [hatha] (example 38).

The field of deixis is a wide one even in one language, let alone in two languages. Several points have been disregarded, others are briefly discussed. Nevertheless, it is hoped that the discussion in this Article is helpful for teachers and translators concerned with English and Arabic in particular and other languages in general.

\section{References}

Bühler, K. (1934). Sprachtheorie: Die Darstellungsfunktion der Sprache. 3 Haulage. G. Fischer, Stuttgart

Faulkner, W. (1992). Sound and Fury. London: Everyman's Library . Arabic translation by Jebra Ibrahinm Jabra in 1998. Abu Dhabi: Dar Al-Mada.

Hassan, A. (1975). Al-Nahu Al-Wafi 1. Cairo: Dar Al-Ma’arif.Ibn Abi Rabbihi. (1948). Al-‘Aqdu Al-Faridu 1. Cairo: Matba'at Al-Ta'lif was Al-Tarjama wa Al-Nashir.

Leech, G. N., Short, M. (1983). Style in Fiction: A Linguistic Introduction to English Fictional Prose. Berlin: Ger Levinson, S.C. (1983). Pragmatics. Cambridge: Cambridge University.

Lyons, J. (1977). English Semantics. Cambridge: Cambridge University Press

Peirce, C. (1931\& 1958): Collected Writings (8 Vols.). (Ed. Charles Hartshorne Paul Weiss \& Arthur W Burks). Cambridge, MA: Harvard University Press

Stuttgart/New York: Fischer (UTB 1159). [ungekürzter Neudruck der Ausgabe Jena: Fischer 1934], 2. Das

Organonmodell der Sprache: S. 24-33. 